\title{
HOW GLOBALIZATION IS RELATED TO ENERGY PRODUCTIVITY? (A MATHEMATICAL ANALYSIS ON IRAN'S AGRICULTURAL DATA)
}

\section{MARYAM GHASEMI, REZA MOGHADDASI*, YAAGHOOB ZERAATKISH}

\author{
Department of Agricultural Economics, Extension and Education, Science and Research Branch, Islamic \\ Azad University, Tehran, Iran \\ *Corresponding author: r.moghaddasi@srbiau.ac.ir
}

\begin{abstract}
Agriculture is recognized as a key economic sector for almost all developing nations including Iran. Nowadays, world economy has been highly integrated as economic performance of a given country is more susceptible to policies taken by other countries than four decades ago. So, investigating the possible impacts of this new worldwide phenomenon (globalization) would be a vital issue. This paper is an empirical examination of the association between globalization and energy productivity in the Iran's agriculture context by using time series econometrics techniques including causality and cointegration tests for the period 1967-2018. Main results confirm existence of a unidirectional causality from globalization to agricultural energy productivity. Other findings revealed that every one percent increase in globalization index is expected to lead in 0.75 percent rise in agricultural energy productivity in the long-run. The error correction coefficient is estimated at -0.25 implying that the effect of every shock imposed on the long-run equation would be vanished in just four years.
\end{abstract}

\section{INTRODUCTION}

Energy is categorized among the essential drivers of global development in general and developing nations' economic growth in particular $[19,13,30,31,32]$. Some ecological economists believe that in the biophysical growth model, energy acts as the most influential factor $[27,23,24,26,27,29]$. Also many studies have reported the impact of economic growth on export

Received May 14 ${ }^{\text {th }}, 2020$; accepted June 26th 2020 ; published September 29th 2020.

2010 Mathematics Subject Classification. 62P20, 91G70.

Key words and phrases. energy productivity; globalization; cointegration; error correction model; Iran.

(C2020 Authors retain the copyrights of their papers, and all open access articles are distributed under the terms of the Creative Commons Attribution License. 
(growth-driven export) [20,1,14,33,34]. So, one may think of an association between energy use and export. In other words, trade is an important driver of economic growth and export enhancement promotes the economic activities and, thus, the energy demand $[25,2,17,18,20,22]$. On the other hand, globalization is currently a popular and controversial issue, though often remaining a loose and poorly-defined concept. Sometimes too comprehensively, the term is used to encompass increases in trade and liberalization policies as well as reductions in transportation costs and technology transfer. As far as its impact is concerned, discussion of globalization tends to consider simultaneously its effects on economic growth, employment and income distribution.

As many other developing nations, agriculture plays an important role in the Iranian economy. Based on recent data, it accounts for about $9.8 \%$ of gross domestic product, $22 \%$ of employment and more than $20 \%$ of non-oil exports $\left(\mathrm{CBI}^{1}, 2018\right)$. Also as a member of OPEC ${ }^{2}$, Iran is an example of oil-dominant economies that has provided cheap energy to different sectors, including agriculture, for decades. It has been seeking non-oil export promotion and low dependency on oil export for three decades. So from policy making point of view it would be very informative to know how energy use has affected major economic variables (growth and export) of the sector.

Little empirical studies can be found dealing with the nexus between energy productivity $\left(\mathrm{EP}^{3}\right)$, and globalization $(\mathrm{G})$ in the Iranian agriculture context. Considering the vital role of agriculture in the Iranian economy and rapid development of globalization in the world, the main motivation of current study can be defined as how globalization affects energy productivity in the sector. The remainder of the paper is structured as follows. Next section deals with methodology employed. Section 3 provides main obtained results and discusses, and finally section 4 presents conclusion.

\footnotetext{
${ }^{1}$ Central Bank of the Islamic Republic of Iran

2 Organization of Petroleum Exporting Countries

${ }^{3}$ Energy used per unit of output (agricultural value added in this study)
} 


\section{MATERIALS AND METHODS}

\subsection{Econometric techniques}

In this study the commonly used method in examination of the causal association between two series, namely; Granger causality test is applied. Considering two variables of interest including EP and $\mathrm{G}$ following equations are specified:

$$
\begin{aligned}
& E P_{t}=\sum_{1}^{p} a_{i} G_{t-i}+\sum_{1}^{q} b_{j} E P_{t-j}+e_{1 t} \\
& G_{t}=\sum_{1}^{r} m_{i} E P_{t-i}+\sum_{1}^{s} n_{j} G_{t-j}+e_{2 t}
\end{aligned}
$$

where $\mathrm{p}, \mathrm{q}, \mathrm{r}$, and $\mathrm{s}$ are lags, and $e_{i}$ 's are residuals assumed to possess all favorite statistical features. According to estimation results following alternatives are expected:

$\sum_{1}^{p} a_{i} \neq 0 \rightarrow$ unidirectional causality from $\mathrm{G}$ to EP

$\sum_{1}^{r} m_{i} \neq 0 \rightarrow$ unidirectional causality from EP to $\mathrm{G}$

$\sum_{1}^{p} a_{i} \neq 0$ and $\sum_{1}^{r} m_{i} \neq 0 \rightarrow$ bidirectional causality between $\mathrm{G}$ and $\mathrm{EP}$

$\sum_{1}^{p} a_{i}=0$ and $\sum_{1}^{r} m_{i}=0 \rightarrow$ independent variables

After detecting causal possible causal relationship one should check existence of long-run association between variables. Here the Johansen-Juselius (JJ) test is applied. It lets to estimate not only magnitude of association but also presence of long-run equilibrium relationship between variables. Based on $\mathrm{JJ}$ test, if $\mathrm{Z}_{\mathrm{t}}$ is a vector containing two non-stationary time series $\left(E P_{t}, G_{t}\right)$ then behavior of $\mathrm{Z}$ can be stated via a vector autoregressive process:

$$
Z_{t}=C_{1} Z_{t-1}+\ldots+C_{k} Z_{t-k}+V_{t}
$$

Equation 3 is commonly estimated by the $\mathrm{ML}^{1}$ methodology. In the case of existence of longrun association, the short-run dynamics can be related to long-run stable relationship via vectorerror-correction model (VECM). This model has a very important policy making implication as it reveals how the impact of a shock would be corrected as time passes [13,6,7,8,11,12,15].

\subsection{Data}

All required information for estimation of equations 1-3 is taken from relevant sources including Ministry of Energy, Ministry of Agriculture and CBI. Furthermore annual data for the period spanning from 1967 to 2018 is used in estimation process.

\footnotetext{
${ }^{1}$ Maximum Likelihood
} 


\section{RESULTS AND DISCUSSION}

Descriptive statistics of variables of interest are presented in Table 1.

Table 1. Descriptive statistics

\begin{tabular}{|c|c|c|c|c|c|c|c|}
\hline variable & description & unit of measurement & average & $\min$ & $\max$ & $\begin{array}{l}\text { standard } \\
\text { deviation }\end{array}$ & $\begin{array}{l}\text { growth } \\
\text { rate } \\
(\%)\end{array}$ \\
\hline EP & $\begin{array}{l}\text { agricultural energy } \\
\text { productivity }\end{array}$ & $\begin{array}{l}\text { billion Rials per one } \\
\text { barrel OE energy }\end{array}$ & 12321 & 8925 & 16539 & 1023 & 0.08 \\
\hline G & $\begin{array}{l}\text { KOF globalization } \\
\text { index }\end{array}$ & - & 32.02 & 21.32 & 49.28 & 4.07 & 17.5 \\
\hline
\end{tabular}

Note: OE denotes Oil Equivalent

As Table 1 shows, both variables have followed upward trend. Also, according to figures presented in Table 2 both two variables are non-stationary, so we are allowed to examine possible long-run equilibrium relationship between variables.

Table 2. Results of three unit root tests

\begin{tabular}{lllllll}
\hline variable & KPSS & & PP & \multicolumn{3}{l}{ ADF } \\
\hline \multirow{2}{*}{ EP } & level & first difference & level & first difference & level & first difference \\
G & $0.32^{*}$ & 0.18 & -3.12 & $-5.33^{* *}$ & -1.02 & $-8.49^{* *}$ \\
\hline & $0.85^{*}$ & 0.28 & -1.27 & $-6.75^{* *}$ & -1.13 & $-8.69^{* *}$ \\
\hline
\end{tabular}

Note: Variables are in natural logarithm

Table 3 portrays the output of JJ test of cointegration that clearly confirmed existence of one long-run equilibrium relationship.

Table 3. The results of JJ test

\begin{tabular}{lllll}
\hline & trace statistic & \multicolumn{2}{c}{ maximum eigenvalue statistic } \\
\hline null & value & critical value & value & critical value \\
hypothesis & & $5 \%$ & & $5 \%$ \\
\hline $\mathrm{r}=0^{*}$ & 29.36 & 15.49 & 19.31 & 14.26 \\
$\mathrm{r}=1$ & 1.11 & 6.02 & 2.93 & 3.84 \\
\hline
\end{tabular}


Table 4 reports results of Granger causality test. Existence of one way causal relationship from globalization to energy productivity in agriculture is confirmed. It means that by getting Iranian economy more integrated into the world economy, energy productivity in agriculture will change. This is consistent with some previous studies in the field $[9,28,14,3,4,5]$.

Table 4. Results of causality test

\begin{tabular}{lccc}
\hline null hypothesis & No of observations & F-statistic & probability \\
\hline G doesn't Granger cause EP & 48 & 7.51 & 0.01 \\
EP doesn't Granger cause G & & 0.36 & 0.78
\end{tabular}

Note: variables are in natural logarithm

Moreover, the long-run cointegrating coefficient is estimated at 0.75 implying that by one percent rise in globalization index one could expect 0.75 percent increase in energy productivity in the Iran's agriculture. Some other studies including Adebola, 2011; Apergis and Payne, 2010 have reported same results. In addition, the error correction coefficient is estimated at -0.25 meaning that the impact of any external shock (stemming from policies such as energy price liberalization) is expected to be completely vanished in just four years.

\section{CONCLUSION}

This study empirically dealt with the causal association between energy productivity and globalization in the context of Iranian agriculture. Annual information on two variables of interest is gathered from official national sources. Results obtained from application of Granger causality test reveals existence of a unilateral causal association from globalization to energy productivity in the agriculture sector. Further examinations showed presence of a long-run equilibrium relationship between globalization and energy productivity. Based on estimation results it is expected that one percent increase in globalization index lead to 0.75 raise in energy productivity. Considering direct and relatively strong effect of globalization on energy productivity at one hand and undeniable role of agriculture in Iranian economy at the other hand, taking measures to reduce susceptibility of domestic agriculture from foreign shocks (such as border measures and bilateral trade agreements) is highly recommended. 
Conflicts of Interest: The author(s) declare that there are no conflicts of interest regarding the publication of this paper.

\section{References}

[1] S. Abbas. Causality between exports and economic growth: Investigating suitable trade policy for Pakistan. Eurasian J. Bus. Econ. 5 (2012), 91-98.

[2] S.S. Adebola. Electricity consumption and economic growth: Trivariate investigation in Botswana with capital formation. Int. J. Energy Econ. Policy, 1 (2011), 32-46.

[3] A. Adewuyi, O. Adeniyi. Trade and consumption of energy varieties: Empirical analysis of selected West Africa economies. Renew. Sustain. Energy Rev. 47 (2015), 354-366.

[4] M. Ahmed, M. Azam. Causal nexus between energy consumption and economic growth for high, middle and low income countries using frequency domain analysis. Renew. Sustain. Energy Rev. 60 (2016), 653-678.

[5] G. Altinay, E. Karagol. Electricity consumption and economic growth: Evidence from Turkey. Energy Econ. 27 (2005), 49-56.

[6] N. Apergis, J.E. Payne. Energy consumption and growth in South America: Evidence from a panel error correction model. Energy Econ. 32 (2010), 1421-1426.

[7] V.C.R. Chandran, S. Sharma, K. Madhavan. Electricity consumption-growth nexus: The case of Malaysia. Energy Policy, 38 (2010), 600-612.

[8] J. Chontanawat, L.C. Hunt, R. Pierse. Does energy consumption cause economic growth? Evidence from a systematic study of over 100 countries, J. Policy Model. 30 (2008), 209-220.

[9] M.A. Destek. Renewable energy consumption and economic growth in newly industrialized countries: Evidence from asymmetric causality test. Renew. Energy, 95 (2016), 478-484.

[10] N. Doytch, S. Narayan. An investigation of renewable and non-renewable energy consumption and economic growth nexus using industrial and residential energy consumption. Energy Econ. 68 (2017), $160-176$.

[11]C. Dritsaki. Causal nexus between economic growth, exports and government debt: The case of Greece. Proc. Econ. Finance, 5 (2013), 251-259.

[12] C.Y. Ee. Export-led growth hypothesis: Empirical evidence from selected Sub-Saharan African countries, Proc. Econ. Finance, 35 (2016), 232-240.

[13] A.A.G. Raeeni, S. Hosseini, R. Moghaddasi. How energy consumption is related to agricultural growth and export: An econometric analysis on Iranian data, Energy Reports, 5 (2019), 50-53. 
[14] K.K. Gokmenoglu, Z. Sehnaz, N. Taspinar. The export-led growth: A case study of Costa Rica. Proc. Econ. Finance, 25 (2015), 471-477.

[15] W.S. Jung, P.J. Marshall, Exports, growth and causality in developing countries, J. Develop. Econ. 18 (1985), 1-12.

[16]K. Krisna, A. Ozyildirim, N.R. Swanson. Trade, investment and growth: Nexus, analysis and prognosis, J. Develop. Econ. 70 (2003), 479-499.

[17]J. Lee. Export specialization and economic growth around the world. Econ. Syst. 35 (2011), 45-63.

[18]C.C. Lee, C.P. Chang. Energy consumption and economic growth in Asian economies: A more comprehensive analysis using panel data. Resource Energy Econ. 30 (2008), 50-65.

[19]K. Makun. Cointegration relationship between economic growth, export and electricity consumption: Evidence from Fiji. Adv. Energy. 2 (2015), 1-7.

[20]P.K. Mishra. The dynamics of relationship between exports and economic growth in India. Int. J. Econ. Sci. Appl. Res. 4 (2011), 53-70.

[21] R. Moghaddasi, A.A. Pour. Energy consumption and total factor productivity growth in Iranian agriculture. Energy Rep. 2 (2016), 218-220.

[22] M. Mutascu. A bootstrap panel Granger causality analysis of energy consumption and economic growth in the G7 countries. Renew. Sustain. Energy Rev. 63 (2016), 166-171.

[23]S. Narayan. Predictability within the energy consumption-economic growth nexus: Some evidence from income and regional groups. Econ. Model. 54 (2016), 515-521.

[24]S. Paul, R.N. Bhattacharya. Causality between energy consumption and economic growth in India: A note on conflicting results. Energy Econ. 26 (2004), 977-983.

[25] P. Sadorsky. Energy consumption, output and trade in South America. Energy Econ. 34 (2012), 476488.

[26] M. Shahbaz, M. Zakaria, S.J.H. Shahzad, M.K. Mahalik. The Energy Consumption and Economic Growth Nexus in Top Ten Energy-Consuming Countries: Fresh Evidence from Using the Quantileon-Quantile Approach. Energy Econ. 71 (2018), 282-301.

[27] D.I. Stern. Energy use and economic growth in the USA: A multivariate approach. Energy Econ. 15 (1993), 137-150.

[28]D. Streimikiene, R. Kasperowicz. Review of economic growth and energy consumption: A panel cointegration analysis for EU countries. Renew. Sustain. Energy Rev. 59 (2016), 1545-1549.

[29] R. Sultan. An econometric study of economic growth, energy and exports in Mauritius: implications for trade and climate policy. Int. J. Energy Econ. Policy, 2 (2012), 225-237. 
[30] R.B. Tekin. Economic growth, exports and foreign direct investment in least developed countries: A panel Granger causality analysis. Econ. Model. 29 (2012), 868-878.

[31] M. Trost, S. Bojnec. Causality between public wage bill, exports and economic growth in Slovenia. Econ. Res. J. 28 (2015), 119-131.

[32]G.A. Vamvoukas. Trade liberalization and economic expansion: A sensitivity analysis. South-East. Eur. J. Econ. 1 (2007), 71-88.

[33] H.Y. Yang. A note of the causal relationship between energy and GDP in Taiwan. Energy Econ. 22 (2000), 309-317.

[34] M. Zibaei, M.H. Tarazkar. A study of the short-term and long-term relationship of the value added and energy consumption in the agriculture sector. Bank Agric. Q. J. 6 (2004), 157-171. 